\title{
PENGARUH EKSTRAK ALOE VERA TERHADAP KESEMBUHAN MUKOSA LAMBUNG TIKUS WISTAR YANG DIINDUKSI ASPIRIN
}

\author{
Lili Soetjipto $^{1}$, Achmad Basori ${ }^{2}$, Endang Joewarini ${ }^{2}$ \\ Program Pascasarjana, Departemen Farmakologi, Fakultas Kedokteran, \\ Universitas Airlangga, Surabaya, Indonesia
}

\begin{abstract}
ABSTRAK
Gangguan lambung akibat penggunaan obat aspirin mulai dari erosi sampai luka bahkan terjadi perdarahan insidennya semakin meningkat setiap tahun di seluruh dunia.Kesembuhan luka lambung dimulai dari proliferasi epithel permukaan diikuti epithel kelenjar yang dipicu oleh faktor pertumbuhan yaitu TGF $\alpha$. Aloe vera telah terbukti sejak jaman dahulu digunakan anti inflamasi / anti ulcer juga sebagai bahan memperlancar buang air besar. Tujuan penelitian ini adalah untuk membuktikan bahwa ekstrak daun lidah buaya (aloe vera ) dapat meningkatkan ekspresi TGF $\alpha$ pada luka lambung tikus yang diinduksi aspirin. Penelitian inin merupakan penelitian eksperimental laboratoris menggunakan rancang bangun acak lengkap dengan post tes only control group design pada tiga puluh tikus putih jantan galur wistar yang dibagi menjadi lima kelompok, empat kelompok mendapat induksi aspirin kemudian

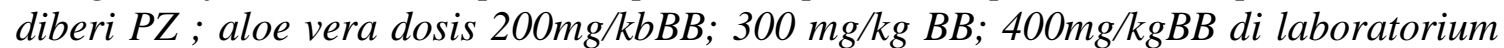
Biokimia Fakultas Kedokteran Universitas Airlangga. Pemeriksaan kesembuhan mukosa lambung dilakukan dengan pengecatan HE di laboratorium Patologi Anatomi Fakultas Kedokteran Universitas Airlangga. Data analisis secara statistik dengan uji Mann Whitney untuk menilai perbedaan jumlah sel fibroblas dan jumlah pembuluh darah baru pada masing- masing kelompok. Hasil penelitian menunjukkan adanya perbedaan bermakna jumlah fibroblas antara kelompok yang mendapat terapi aloe vera dibanding kelompok tanpa terapi aloe vera, terdapat berbedaan bermakna jumlah fibroblas tiap- tiap kelompok dengan peningkatan dosis aloe vera. Terdapat perbedaan pembuluh darah baru pada kelompok mendapat terapi aloe vera dengan kelompok tanpa terapi aloe vera namun peningkatan dosis aloe vera tidak ada perbedaan bermakna.
\end{abstract}

Kata kunci : Aloe vera ; luka lambung ; fibroblas ; pembuluh darah baru 


\section{Pendahuluan}

Aspirin merupakan golongan obat yang sangat sering digunakan untuk meredakan keluhan. Dosis kecil aspirin sering digunakan sebagai pencegahan kasus serebrovaskuler maupun kardiovaskuler sehingga digunakan jangka panjang. Obat golongan ini digunakan hampir semua umur tetapi paling sering digunakan pada dewasa dan usia lanjut. Penggunaan jangka panjang aspirin (lebih dari 3 bulan) dosis berapapun dapat menurunkan jumlah mukus akibat produksi prostaglandin menurun serta menginduksi jejas pada mukosa lambung. Manifestasi klinis gastropati OAINS bervariasi dari tanpa gejala, gejala ringan seperti dispepsia, rasa sebah,mual hingga gejala berat seperti tukak lambung, perdarahan bahkan perforasi .

Kesembuhan gastropati terdiri dari respon lokal dan sistemik,melibatkan beberapa proses yang berjalan tumpang tindih, yaitu : homeostasis ,inflamasi, proliferasi epithel selama 14 hari diikuti dengan proliferasi mukosa dan submukosa. Proses dilanjutkan dengan remodeling kelenjar lambung akan berjalan hingga hari ke 60. Pada proses inflamasi akan terjadi migrasi sel darah putih yaitu neutrofil pada fase akut yang selanjutnya diikuti oleh makrofag. Makrofag mempunyai fungsi debridemen, mikrobisidal dan penyembuhan luka. Proses yang terjadi adalah pelepasan berbagai mediator inflamasi, sitokin serta faktor pertumbuhan. Salah satu faktor pertumbuhan yang berperan dalam proses penyembuhan adalah Transforming Growth Factor ( TGF). Ada dua macam TGF yaitu TGF $\alpha$ dan TGF $\beta$. TGF $\alpha$ mempunyai peran yang lebih besar pada jaringan mukosa karena memicu migrasi epithel sehingga terjadi epithelialisasi serta memicu produksi bFGF dan VEGF yang akan menstimuli proliferasi sel fibroblas dan endotel kapiler sehingga terbentuk pembuluh darah baru.

Aloe Vera, adalah salah satu tanaman penyembuh yang paling banyak digunakan. Di India semua bagian aloe vera baik daun,getah dan gel digunakan sebagai pencahar, obat sakit perut, anti mual muntah, dan anti cacing. Berbagai penelitian membuktikan bahwa tanaman aloe vera memilikki efek anti inflamasi, anti oksidan, anti luka/wound healing, anti mikroba, laxative. Efek tersebut didapat dari kandungan daun Aloe vera yaitu polisakarida yang paling dikenal sebagai accemannan, manose berikatan dengan reseptor manoose di makrofag sehingga meninduksi produksi growth faktor termasuk TGF $\alpha$ (Tranforming Growth factor $\alpha$ ) yang akan mengaktifkan MAP Kinase sehingga memicu ekspresi bFGF dan VEGF fibroblas akan merangsang sintesa dan proliferasi fibroblas yang akan meningkatkan pembentukan kolagen.

\section{Materi dan metode}

Penelitian ini merupakan penelitian eksperimental dengan rancangan randomized control post tes only control group only pada hewan tikus wistar. Tiga puluh ekor tikus wistar jantan dibagi menjadi 5 kelompok secara acak. K1 : kelompok tanpa induksi aspirin ( kontrol negatif ), K2 : kelompok dengan induksi aspirin dan terapi PZ ( kelompok positif ), K3 : kelompok dengan induksi aspirin dan terapi aloe vera

$200 \mathrm{mg} / \mathrm{kg} \quad \mathrm{BB}, \quad \mathrm{K} 4 \quad$ : kelompok dengan induksi aspirin dan terapi aloe vera $300 \mathrm{mg} / \mathrm{kg} \mathrm{BB}, \mathrm{K} 5$ : kelompok dengan induksi aspirin dan terapi aloe vera $400 \mathrm{mg} / \mathrm{kg}$ BB. Tikus dipuasakan 24 jam sebelum lalu diberi aspirin dengan dosis $250 \mathrm{mg} / \mathrm{kg}$ BB 2 kali sehari 
selang 12 jam per oral ( sonde ) kemudian dipuasakan

24 jam sebelum pemberian PZ dan ekstak aloe vera. Proses ekstrak aloe vera dilakukan di Materia Medika Batu dengan ektrak ethanol dan diberikan secara oral. Setelah pemberian ekstrak aloe vera selama 6 ( enam ) hari berturut - turut dilakukan terminasi dengan menggunakan ether dan diambil jaringan lambung untuk dilakukan pemeriksaan pathologi anatomi dengan pewarnaan HE kemudian dihitung jumlah fibroblas dan pembuluh darah baru.

\section{Hasil penelitian}

Dari uji kruskal walis diperoleh $\mathrm{p}<0,05$ yang berarti terdapat perbedaan bermakna jumlah fibroblas. Selanjutnya dilakukan uji Mann Whitney untuk melihat perbedaan tiap 2 kelompok. Hasil uji Mann whitney menunjukkan bahwa Secara statistik terdapat perbedaan bermakna antar kelompok K2 dengan $\mathrm{K} 1$, kelompok yang mendapat terapi aloe vera $(\mathrm{K} 3, \mathrm{~K} 4, \mathrm{~K} 5)$ terhadap kelompok yang tidak mendapat terapi aloe vera (K2 dan K1), juga antar kelompok $\mathrm{K} 3, \mathrm{~K} 4, \mathrm{~K} 5$.

Tabel 1. Hasil uji Mann Whitney jumlah fibroblast

\begin{tabular}{|l|l|l|l|l|l|}
\hline & $\begin{array}{l}\mathrm{K} \\
1\end{array}$ & $\mathrm{~K} 2$ & $\mathrm{~K} 3$ & $\mathrm{~K} 4$ & $\mathrm{~K} 5$ \\
\hline $\mathrm{K}$ & & 0,00 & 0,00 & 0,00 & 0,00 \\
1 & & 4 & 4 & 4 & 4 \\
\hline $\mathrm{K}$ & & & 0,00 & 0,00 & 0,00 \\
2 & & & 4 & 4 & 4 \\
\hline $\mathrm{K}$ & & & & 0,00 & 0,00 \\
3 & & & & 4 & 4 \\
\hline $\mathrm{K}$ & & & & & 0,05 \\
4 & & & & & \\
\hline $\mathrm{K}$ & & & & & \\
5 & & & & & \\
\hline
\end{tabular}

Hasil pengolahan data jumlah fibroblas diperoleh nilai rerata dan simpangan deviasi dan pada pemeriksaa nuji normalitas jumlah pembuluh darah baru didapatkan kelompok $\mathrm{K} 1, \mathrm{~K} 2$ dan $\mathrm{K} 4$ memiliki distribusi tidak normal maka selanjutnya dilakukan uji Kruskal Wallis untuk membedakan lebih dari 2 kelompok. Hasil uji Kruskal Wallis untuk membedakan lebih dari 2 kelompok diperoleh $\mathrm{p}<0,05$ yang berarti terdapat perbedaan bermakna jumlah pembuluh darah, Selanjutnya dilakukan uji Mann Whitney untuk melihat perbedaan tiap 2 kelompok

\begin{tabular}{|l|l|l|l|l|l|}
\hline & $\mathrm{K} 1$ & $\mathrm{~K} 2$ & $\mathrm{~K} 3$ & $\mathrm{~K} 4$ & $\mathrm{~K} 5$ \\
\hline $\mathrm{K} 1$ & & 0,003 & 0,003 & 0,003 & $\begin{array}{l}0,00 \\
3\end{array}$ \\
\hline K2 & & & 0,212 & 0,007 & $\begin{array}{l}0,00 \\
8\end{array}$ \\
\hline K3 & & & & 0,057 & $\begin{array}{l}0,04 \\
4\end{array}$ \\
\hline K4 & & & & & 0,48 \\
& & & & & 4 \\
\hline K5 & & & & & \\
\hline
\end{tabular}

Secara statistic terdapat perbedaan bermakna kelompok K2,K3,K4,K5 dibandingkan kelompok $\mathrm{K} 1$, selain itu juga terdapat perbedaan bermakna pada kelompok $\mathrm{K} 4, \mathrm{~K} 5$ dibanding kelompok $\mathrm{K} 2, \mathrm{~K} 3$ namun tidak terdapat perbedaan bermakna antara kelompok K4 dan K5.

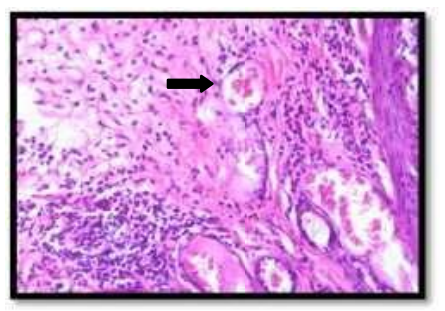

Gambar 1.pemeriksaan histopatologi, panah hitam menunjukkan pembuluh darah baru. 


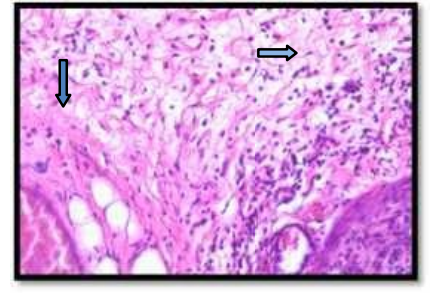

Gambar 2. Panah bitu menunjukkan sel fibroblas

\section{Diskusi}

Proses penyembuhan luka lambung dimulai dengan pembentukan zona penyembuhan dimana terjadi ekspresi faktor pertumbuhan yang akan membentuk tepi luka dan mulai terjadi pembentukan jaringan granulasi pada dasar luka selanjutnya akan terjadi remodeling. Pada fase selanjutnya sel dan mediator inflamasi akan digantikan oleh fibroblas dan pembuluh darah kapiler. Organisasi paling awal terjadi beberapa hari setelah dimulainya reaksi peradangan, setelah satu minggu jaringa granulasi masih longgar dan selular. Pada saat ini fibroblas jaringan granulasi sedikit demi sedikit mulai mensekresi prekusor protein kolagen yang larut, sedikit demi sedikit akan mengendap sebagai fibril dalam interstitial jaringa granulasi. Pada penelitian ini pemberian aloe vera meningkatkan jumlah fibroblas bahkan peningkatan dosis aloe vera juga meningkatkan jumlah fibroblas. Hipoksia saat terjadi luka karena kerusakan pembuluh darah akan menginduksi ekspresi VEGF. TGF $\alpha$ akan mengaktifkan
MAP Kinase yang akan meninduksi ekspresi VEGF selanjutnya akan memicu proliferasi sel endotel kapiler sehingga terbentuk pembuluh darah baru sehingga nutrisi untuk proses kesembuhan bisa berlangsung, selain itu sel endothel yang teraktivasi akan memproduksi protease ( matriks metallo protein /MMP ) untuk mencerna lamina basalis pada pembuluh darah induk untuk merayap melalui ECM dan berkumpul membentuk pembuluh darah baru pada bagian tengah luka . Hasil penelitian ini menunjukkan bahwa pemberian aloe vera dapat meningkatkan jumlah pembuluh darah baru meskipun pada peningkatan dosis aloe vera tidak terdapat peningkatan jumlah pembuluh darah baru hal ini ungkin karena pemeriksaan dilakukan pada hari ke enam dimana proses ekspresi VEGF sudah menurun sehingga sudah tidah diperlukan lagi pembentukan pembuluh darah baru.

\section{Kesimpulan}

Pemberian ekstrak aloe vera cukup signifikan dalam membantu proses kesembuhan luka lambung yang diinduksi aspirin terbukti adanya peningkatan pembentukan fibrobla pada dan pembuluh darah baru. 


\section{Ucapan terima kasih}

Saya ingin menyampaikan terima kasih yang sebesar-besarnya kepada seluruh staf Departemen Farmakologi dan Departemen Pathologi Anatomi Fakultas Kedokteran Universitas Airlangga yang selalu memberikan dukungan penuh selama sya menempuh program pasca sarjana berkaitan dengan penelitian di Fakultas Kedokteran Universitas Airlangga.

\section{Referensi}

Matteo Fornai, Luca Antonioli, Rocchina Colucci, Marco Tuccori and Corrado Blandizzi, .(2011) Pathophysiology of gastric ulcer development and healing : molecular mechanisms and novel therapeutic options

Kumar V, S.A Bustin, I.A.Mc Kay,

Transforming growth factor Alpha,

Cell Biology International, vol.19, No.5, 1995

Pankaj K. Sahu, Deen Dayal Giri, Ritu Singh, Priyanka Pandey, Sharmistha Gupta, Atul Kumar Shrivastava, Ajay Kumar, Kapil Dev Pandey, Therapeutic and Medicinal Uses of Aloe vera: A Review , Pharmacology \& Pharmacy, 2013, 4, 599-610

Priyanka Sharma, Amit C Kharwal, Harsha Kharwal, M Z Abdin, Ajit
Varma, , (2014).A review Pharmacological Properties of Aloe Vera, review article Tarnawski, A.S, Ahluwalai, A., Jones, M.K., (2012) The mechanism of gastric mucosal injury : Focus on microvascular endothelium as a key target . current Medicinal Chemistry, $19(1), 4-5$. 